\title{
Improving the Catalytic Activity of Hyperthermophilic Pyrococcus horikoshii Prolidase for Detoxification of Organophosphorus Nerve Agents over a Broad Range of Temperatures
}

\author{
Casey M. Theriot, ${ }^{1}$ Rebecca L. Semcer, ${ }^{2}$ Saumil S. Shah, ${ }^{3}$ and Amy M. Grunden ${ }^{2}$ \\ ${ }^{1}$ Division of Infectious Diseases, Department of Internal Medicine, The University of Michigan, Ann Arbor, MI 48109, USA \\ ${ }^{2}$ Department of Microbiology, North Carolina State University, Campus Box 7615, Raleigh, NC 27695-7615, USA \\ ${ }^{3}$ Biochemistry Branch, US Army Edgewood Chemical Biological Center, E3150 North Kingscreek Road, Aberdeen Proving Ground, \\ Aberdeen, MD 21010-5183, USA
}

Correspondence should be addressed to Amy M. Grunden, amy_grunden@ncsu.edu

Received 14 June 2011; Accepted 1 September 2011

Academic Editor: Jerry Eichler

Copyright (C) 2011 Casey M. Theriot et al. This is an open access article distributed under the Creative Commons Attribution License, which permits unrestricted use, distribution, and reproduction in any medium, provided the original work is properly cited.

Prolidases hydrolyze Xaa-Pro dipeptides and can also cleave the P-F and P-O bonds found in organophosphorus (OP) compounds, including the nerve agents soman and sarin. Ph1prol (PH0974) has previously been isolated and characterized from Pyrococcus horikoshii and was shown to have higher catalytic activity over a broader $\mathrm{pH}$ range, higher affinity for metal, and increased thermostability compared to $P$. furiosus prolidase, $P f$ prol (PF1343). To obtain a better enzyme for OP nerve agent decontamination and to investigate the structural factors that may influence protein thermostability and thermoactivity, randomly mutated $P h 1$ prol enzymes were prepared. Four Ph1prol mutants (A195T/G306S-, Y301C/K342N-, E127G/E252D-, and E36V-Ph1prol) were isolated which had greater thermostability and improved activity over a broader range of temperatures against Xaa-Pro dipeptides and OP nerve agents compared to wild type Pyrococcus prolidases.

\section{Introduction}

Pyrococcus horikoshii and Pyrococcus furiosus are both hyperthermophilic archaea, growing optimally at $98-100^{\circ} \mathrm{C}$ that were isolated from a deep hydrothermal vent in the Okinawa Trough in the northeastern Pacific Ocean and from a shallow marine solfatara at Vulcano Island off the coast of Italy, respectively [1, 2]. Pyrococcus spp. are some of the most studied hyperthermophilic archaea to date owing in part to their utility for a variety of biotechnological applications [3-7]. For example, recombinant prolidases from Pyrococcus spp. are being studied for their potential use in bio-decontamination applications [8].

Prolidases function in vivo to hydrolyze dipeptides with proline in the C-terminus, Xaa-Pro, and a non-polar amino acid in the N-terminus [9]. However, studies have demonstrated that prolidases can also hydrolyze and detoxify organophosphate (OP) compounds such as chemical warfare agents (CWA) [8]. Two enzymes that have been characterized for potential field detoxification of nerve agents are organophosphorus acid anhydrolase (OPAA) and phosphotriesterase (PTE) [10, 11]. Recently, the crystal structure of OPAA from Alteromonas sp. JD6.5 strain has been solved, and it has been determined to be a prolidase [12]. While OPAA does have the capability to degrade OP nerve agents, its activity can be limited by exposure to high temperatures and solvents during use in field situations $[13,14]$.

In 2008, the Defense Threat Reduction Agency (DTRA), under the auspices of the Department of Defense recognized the importance of developing enzyme-based OP nerve agent detoxification systems and created an initiative calling for new enzymes and biocatalysts that are stable over a broad temperature and $\mathrm{pH}$ range, in the presence of salts and surfactants, and that do not pose an environmental hazard 
[15]. In response to the need to develop stable OP nerve agent degrading enzyme systems, thermostable prolidases from Pyrococcus spp. were studied [16-18].

Specifically, Pyrococcus prolidases from $P$. furiosus (PF1343 or Pfprol) and P. horikoshii (PH1149 or Phprol and PH0974 or Ph1prol) were characterized both structurally and enzymatically $[16,18,19]$. The Pyrococcus prolidases were determined to be very similar, with $P f$ prol showing $88 \%$ amino acid similarity to $P h$ prol and $55 \%$ similarity to Phlprol. Although they have high similarity to each other, the kinetic properties of Phlprol appeared to be more favorable for application purposes than those of $P f$ prol and Phprol. Phlprol has demonstrated higher activity at lower temperatures and over a broader $\mathrm{pH}$ range. It has long-term stability, higher affinity for substrates, and a lower metal requirement for catalysis [16]. Therefore, it was deemed to be advantageous to use Phlprol in mutagenesis studies in order to develop a better enzyme for OP nerve agent detoxification and to further investigate factors that influence the catalysis of thermophilic metalloenzymes. To this end, a random mutagenesis Phlprol gene library was constructed and screened for production of mutants that showed increased prolidase activity at $30^{\circ} \mathrm{C}$ compared to wild type Phlprol. Four Phlprol mutants were isolated and subsequently characterized to determine their substrate catalysis over a broad range of temperatures and their performance against OP nerve agent analogs in comparison to Phlprol and the previously characterized $P f$ prol.

\section{Materials and Methods}

2.1. Bacterial Strains, Media, and Materials. The E. coli K12 derivative NK5525 (proA::Tn10) was used to construct the selection strain JD1( $\lambda$ DE3) as described in [20] for screening of cold-adapted $P$. horikoshii prolidase variants. The $P$. horikoshii prolidase expression plasmid pET-Ph1prol was previously constructed as described in [16]. The E. coli strains were cultured either in Luria-Bertani (LB) broth or M9 selective minimal medium supplemented with $0.2 \%$ glucose, $1 \mathrm{mM}$ MgSO4, 0.05\% VitB, $20 \mu \mathrm{M}$ IPTG, $20 \mu \mathrm{M}$ Leu-Pro. Ampicillin $(100 \mu \mathrm{g} / \mathrm{mL})$, kanamycin $(50 \mu \mathrm{g} / \mathrm{mL})$, chloramphenicol $(34 \mu \mathrm{g} / \mathrm{mL})$, and tetracycline $(6 \mu \mathrm{g} / \mathrm{mL})$ were added into the medium when required.

\subsection{Construction of a Pool of pET-Ph1prol Plasmids Encoding} Randomly Mutated P. horikoshii Prolidase Genes. Errorprone PCR mutagenesis using the Genemorph II Random mutagenesis kit (Stratagene, La Jolla, Calif) was used to amplify and insert mutations into the P. horikoshii prolidase gene (PH0974). PCR amplification was carried out for 30 cycles: $\left(60 \mathrm{sec}\right.$ at $95^{\circ} \mathrm{C}, 60 \mathrm{sec}$ at $55^{\circ} \mathrm{C}, 120 \mathrm{sec}$ at $72^{\circ} \mathrm{C}$ ), with a 10 -minute final extension at $72^{\circ} \mathrm{C}$. Reactions contained Mutazyme II reaction buffer, $125 \mathrm{ng} / \mu \mathrm{L}$ of each primer, $40 \mathrm{mM}$ dNTP mix, and $2.5 \mathrm{U}$ of Mutazyme II DNA polymerase. Initial DNA template amounts used were $250 \mathrm{ng}$ and $750 \mathrm{ng}$ in order to select for medium-to-low mutation rates, respectively. The Genemorph II EZClone (Stratagene,
La Jolla, Calif) reaction was employed to clone the mutated prolidase gene into the expression vector pET-21b.

The EZClone reaction included EZClone enzyme mix, $50 \mathrm{ng}$ of template plasmid (pET-prol), $500 \mathrm{ng}$ of megaprimer (mutated prolidase PCR product), and EZClone solution. The reactions were amplified for 25 cycles: $\left(50 \mathrm{sec}\right.$ at $95^{\circ} \mathrm{C}$, $50 \mathrm{sec}$ at $60^{\circ} \mathrm{C}, 14 \mathrm{~min}$ at $68^{\circ} \mathrm{C}$ ). Amplified products were digested with $D p n I$ for 2 hours at $37^{\circ} \mathrm{C}$ to remove template plasmid. XL1-Gold super competent E. coli cells were transformed with the mutant plasmid mixture.

2.3. Screening for Increased Activity at Low Temperature. pET-Ph1prol plasmids from the mutant $P$. horikoshii library were transformed into the selective strain JD1 $(\lambda \mathrm{DE} 3)$ and were plated on M9 selective agar plates. Colonies that grew after being incubated for $3-7 \mathrm{~d}$ at $20^{\circ} \mathrm{C}$ were isolated on $\mathrm{LB}$ plates and then grown in $10 \mathrm{~mL} \mathrm{LB}$ medium at $37^{\circ} \mathrm{C}$ with shaking $(200 \mathrm{rpm})$ until an optical density of $0.6-0.8$ was reached. IPTG was then added to the cell culture to a final concentration of $1 \mathrm{mM}$. The induced culture was shaken at $37^{\circ} \mathrm{C}$ for $3 \mathrm{~h}$ before harvesting the cells. These cell pellets were lysed using $300 \mu \mathrm{L}$ of B-per buffer (Thermo Scientific, Rockford, Ill), and the resulting cell extracts were used for enzyme activity assays conducted at $30^{\circ} \mathrm{C}$ and at $100^{\circ} \mathrm{C}$. Heat-treated soluble protein samples were heated at $80^{\circ} \mathrm{C}$ for $20 \mathrm{~min}$. Four mutant colonies that exhibited at least 2-3-fold higher activities compared to the cells expressing the wild type $P$. horikoshii prolidase were selected for characterization, and their plasmids were isolated. The prolidase genes present in those isolated plasmids were sequenced using the T7 promoter and T7 terminator primers (MWG Biotech, Huntsville, AL).

2.4. Large-Scale Expression of Recombinant P. horikoshii Prolidase Mutants. Production of $P$. horikoshii prolidase variants (A195T/G306S-, Y301C/K342N-, E127G/E252D-, and E36VPh1prol) was carried out in transformed E. coli BL21 ( $\lambda$ DE3) cells with the appropriate pET-Ph1prol plasmid and pRIL vector. The transformants were grown in $1 \mathrm{~L}$ cultures of autoinduction media [21] incubated at $37^{\circ} \mathrm{C}$ with shaking (200 RPM) overnight.

2.5. Purification of Recombinant P. horikoshii Prolidase Mutants. Cell pellets from the four Phlprol variants (A195T/G306S-, Y301C/K342N-, E127G/E252D-, and E36VPh1prol) were suspended in $50 \mathrm{mM}$ Tris- $\mathrm{HCl}, \mathrm{pH} 8.0(3 \mathrm{~mL}$ Tris per 1 gram of cell paste), with $1 \mathrm{mM}$ benzamidine and $1 \mathrm{mM}$ DTT. For each variant, diluted cell slurry was passed through a French pressure cell $\left(20,000 \mathrm{lb} / \mathrm{in}^{2}\right)$ three times. Cell lysates were centrifuged at $38,720 \mathrm{xg}$ for $30 \mathrm{~min}$ at $4^{\circ} \mathrm{C}$, and then the supernatants were heated to $80^{\circ} \mathrm{C}$ for $30 \mathrm{~min}$ anaerobically to denature any proteins not stable at that temperature. Heat-treated supernatants were centrifuged at $38,720 \mathrm{xg}$ to remove the denatured proteins. Supernatants were sampled both before and after heat treatment for activity analysis. $\left(\mathrm{NH}_{4}\right)_{2} \mathrm{SO}_{4}$ was added gradually to the supernatants to make a final concentration of $1.5 \mathrm{M}$ prior to loading onto a $5 \mathrm{~mL}$ Phenyl-Sepharose hydrophobic 
interaction chromatography column (Hi-Trap Phenyl HP Column, GE Healthcare Life Sciences, Piscataway, NJ). Fractions containing the prolidase mutants were pooled and dialyzed overnight into $4 \mathrm{~L}$ of $50 \mathrm{mM}$ Tris $\mathrm{HCl}, \mathrm{pH} 8.0$ at $4^{\circ} \mathrm{C}$, and were further purified on a $5 \mathrm{~mL}$ Q Sepharose anion exchange chromatography column (Hi-Trap Q FF Column, GE Healthcare Life Sciences, Piscataway, NJ). Buffers for both purification steps have been described in [16]. Fractions from both purification steps were further visualized using SDS-PAGE (12.5\% SDS-polyacrylamide gels) and were tested for enzyme activity. Fractions were then pooled based on gel images, and enzyme stocks were stored at $-80^{\circ} \mathrm{C}$. The molecular weights of $P h 1$ prol and mutants are approximately $40.04 \mathrm{kDa}$. The purity of each Phlprol mutant was estimated to be greater than $95 \%$ using both visual inspection of SDSpolyacrylamide gels and electrophoretic microchip analysis.

2.6. Prolidase Enzyme Activity Assay. The enzyme activity assay protocol is based on a method previously described by $[17,20]$. The reaction mixture $(500 \mu \mathrm{L})$ contained $50 \mathrm{mM}$ MOPS buffer (3-[N-morpholino] propanesulfonic acid) $\mathrm{pH}$ 7.0, $200 \mathrm{mM} \mathrm{NaCl}$, water, $5 \%$ (vol/vol) glycerol, $100 \mu \mathrm{g} / \mathrm{mL}$ BSA (bovine serum albumin) protein, $0.2 \mathrm{mM} \mathrm{CoCl}_{2}$, and the enzyme. The reaction mixture was heated at $100^{\circ} \mathrm{C}$ for 5 min allowing time for the metal and enzyme to interact. The reaction was initiated by the addition of substrate (XaaPro, $4 \mathrm{mM}$ final concentration) and allowed to proceed for $10 \mathrm{~min}$ at $100^{\circ} \mathrm{C}$. The reaction was stopped with $500 \mu \mathrm{L}$ glacial acetic acid and $500 \mu \mathrm{L}$ ninhydrin reagent (3\% (wt. vol)) and heated again for $10 \mathrm{~min}$ at $100^{\circ} \mathrm{C}$. The reaction was then cooled to $23^{\circ} \mathrm{C}$. Prolidase samples were assayed in triplicate and specific activity was calculated using the absorbance value at $515 \mathrm{~nm}$ and an extinction coefficient of $4,570 \mathrm{M}^{-1} \mathrm{~cm}^{-1}$ for the ninhydrin-proline complex.

For assays evaluating the temperature profile, WTPhlprol and the four prolidase mutants were assayed in triplicate for activity with $4 \mathrm{mM}$ Met-Pro at $10^{\circ} \mathrm{C}, 20^{\circ} \mathrm{C}$, $35^{\circ} \mathrm{C}, 50^{\circ} \mathrm{C}, 70^{\circ} \mathrm{C}$, and $100^{\circ} \mathrm{C}$. Experiments were performed in duplicate.

2.7. Substrate Specificity and Kinetics Experiments. In order to study substrate specificity, the following Xaa-Pro dipeptides were used as substrates ( $4 \mathrm{mM}$ final concentration) in the enzyme activity assays for WT-Phlprol and the four prolidase mutants: Val-Pro, Met-Pro, Phe-Pro, Leu-Pro, AlaPro, and Gly-Pro. Prolidase samples were assayed with two additional substrates, Pro-Ala and Val-Leu-Pro, to further illustrate prolidase preference of Xaa-Pro dipeptides [20]. Kinetic parameters of the $P h 1$ prol mutants were determined at $70^{\circ} \mathrm{C}$ using a range of Leu-Pro concentrations (0.25$12 \mathrm{mM})$.

2.8. Thermostability and Pot-Life Experiments. Thermostability experiments were performed in duplicate on WTPhlprol and the four mutants. Each enzyme was diluted to a concentration of $0.04 \mathrm{mg} / \mathrm{mL}$ in $50 \mathrm{mM}$ MOPS, $\mathrm{pH} 7.0$, and $200 \mathrm{mM} \mathrm{NaCl}$ and incubated in an anaerobic sealed vial at $90^{\circ} \mathrm{C}$. An initial sample was taken to represent Time $=0 \mathrm{~h}$, and additional samples were taken at Time $=24,48$, and $72 \mathrm{~h}$. Samples were diluted to $0.4 \mu \mathrm{g} / \mathrm{mL}$ in $50 \mathrm{mM}$ MOPS, $\mathrm{pH}$ 7.0 , and $200 \mathrm{mM} \mathrm{NaCl}$ and were then assayed in triplicate in accordance with the enzyme activity assay protocol described in Section 2.6. In all cases, the substrate used in the activity assay was $4 \mathrm{mM}$ Met-Pro.

Pot-life experiments were also performed in duplicate. Each enzyme was diluted to a concentration of $0.04 \mathrm{mg} / \mathrm{mL}$ in $50 \mathrm{mM}$ MOPS, $\mathrm{pH} 7.0$, and $200 \mathrm{mM} \mathrm{NaCl}$ and incubated anaerobically in a sealed vial at $70^{\circ} \mathrm{C}$. An initial sample was taken to represent Time $=0$ days, and additional samples were taken at Time $=1,7,14,16$, and 21 days. Samples were diluted to $0.4 \mu \mathrm{g} / \mathrm{mL}$ in $50 \mathrm{mM}$ MOPS, $\mathrm{pH} 7.0$, and $200 \mathrm{mM}$ $\mathrm{NaCl}$ and were then assayed in triplicate to determine specific activity.

2.9. DSC Experiment. Differential scanning calorimetry was performed using a MicroCal VP-DSC scanning calorimeter. The calorimetric samples contained $\sim 1 \mathrm{mg} / \mathrm{mL}$ protein in $50 \mathrm{mM}$ MOPS, $200 \mathrm{mM} \mathrm{NaCl}, 0.2 \mathrm{mM} \mathrm{CoCl}$, pH 7.0. Protein samples were dialyzed $15 \mathrm{~h}$ against this buffer before the experiment. Samples were degassed before loading into the chamber cell. The calorimetric experiment was performed by heating the samples at a scan rate of $100^{\circ} \mathrm{C} / \mathrm{hr}$.

2.10. DFP (diisopropylfluorophosphate) Assay. The hydrolysis of DFP by prolidases was measured by monitoring fluoride release with a fluoride-specific electrode as previously described [22]. Assays were performed at $35^{\circ} \mathrm{C}$ and $50^{\circ} \mathrm{C}$, with continuous stirring in $2.5 \mathrm{~mL}$ of buffer ( $50 \mathrm{mM}$ MOPS, $200 \mathrm{mM} \mathrm{NaCl}, \mathrm{pH} 7.0$ ), $0.2 \mathrm{mM} \mathrm{CoCl}_{2}$ and $3 \mathrm{mM}$ DFP. The enzyme and metal were incubated at the reaction temperature $5 \mathrm{~min}$ prior to the start of the reaction. The background of DFP hydrolysis was measured by running a reaction without enzyme present at $35^{\circ} \mathrm{C}$ and $50^{\circ} \mathrm{C}$. The background hydrolysis of DFP was subtracted from enzymatic hydrolysis to determine specific activity of the enzyme.

2.11. p-Nitrophenyl Soman Assay (O-Pinacolyl p-Nitrophenyl Methylphosphonate Activity). Prolidase hydrolysis of $p$ nitrophenyl soman was monitored by accumulation of $p$ nitrophenolate $[10,22]$. The $\mathrm{p}$-Nitrophenyl Soman was synthesized at Edgewood Chemical Biological Center in Aberdeen Proving Ground, Md. and contained a racemic mixture of all four stereoisomers. The purity of the soman analog was greater than $90 \%$ based on gas chromatography analysis [12]. Two $\mathrm{mL}$ reaction assays contained buffer (50 mM MOPS, $200 \mathrm{mM} \mathrm{NaCl}, \mathrm{pH} 7.0$ ), $0.2 \mathrm{mM} \mathrm{CoCl}_{2}$, and $0.3 \mathrm{mM}$ p-nitrophenyl soman. The reactions were conducted at three different temperatures $\left(35^{\circ} \mathrm{C}, 50^{\circ} \mathrm{C}\right.$ and $\left.70^{\circ} \mathrm{C}\right)$. The enzyme and metal were incubated at the specified reaction temperature $5 \mathrm{~min}$ prior to the start of the reaction. Absorbance of the product $p$-nitrophenolate was measured at $405 \mathrm{~nm}$ over a $5 \mathrm{~min}$ range. To calculate activity, the extinction coefficient for $p$-nitrophenolate of $10,101 \mathrm{M}^{-1} \mathrm{~cm}^{-1}$ was used. 


\section{Results and Discussion}

3.1. P. furiosus and P. horikoshii Prolidase-Specific Activities with OP Nerve Agents: DFP and Soman Analog. Previous studies characterizing $P$. horikoshii prolidase homolog 1 (Ph1prol, PH0974) demonstrated that it has higher catalytic activity over a broader $\mathrm{pH}$ range, higher affinity for metal, and is more thermostable than either $P$. furiosus prolidase (Pf prol, PF1343) or P. horikoshii prolidase (Phprol, PH1149) when assayed with the dipeptide substrate Met-Pro [20]. Based on these favorable attributes for $P h 1$ prol when reacting with its natural substrates, Xaa-Pro dipeptides, there was interest in determining the relative activity of recombinant Phlprol compared to $P f$ prol and Phprol against Gtype nerve agent simulants DFP and soman analog, $p$ nitrophenylsoman. As indicated in Figure 1, DFP exhibited the greatest hydrolysis with $P h 1$ prol. Phlprol had a relative activity that was $843 \%$ higher than $P f$ prol and $817 \%$ higher than Phprol at $35^{\circ} \mathrm{C}$ and $1870 \%$ higher than both $P f$ prol and Phprol at $50^{\circ} \mathrm{C}$ (Figure 1). In contrast, the trends with the soman analog were very different as shown in Figure 2 . The relative activity of Ph1prol was only $70 \%, 63 \%$, and $68 \%$ of the $P f$ prol activity at $35^{\circ} \mathrm{C}, 50^{\circ} \mathrm{C}$, and $70^{\circ} \mathrm{C}$, respectively (Figure 2 ). These results indicate that $\mathrm{Ph} 1$ prol has a preference for DFP and does not exhibit high activity with the soman analog. Differences in the protein structures likely play a role in the substrate preference since $P f$ prol and Ph1prol share only 55\% amino acid residue similarity [16]. By altering the Phlprol structure further using a random mutagenesis approach, it would be possible to isolate Ph1prol variants that show even greater hydrolysis of DFP and/or improved activity against the soman analog.

3.2. Screening and Isolation of the Ph1prol Mutant Population Using Proline Auxotrophic Strain JD1 ( $\lambda D E 3)$. Since Ph1prol showed the most favorable properties including higher activity with DFP, it was selected for further mutagenesis using an error-prone PCR strategy, which employs a mutated polymerase. Transformed E. coli JD1 ( $\lambda \mathrm{DE} 3$ ) cells were used to select for Phlprol variants on minimal media plates that were supplemented with $20 \mu \mathrm{M}$ Leu-Pro and grown at $20^{\circ} \mathrm{C}$. Colonies that were visible in $3-7$ days were plated on minimal and rich (LB) media. Phlprol variants were screened using small-scale expression cultures $(10 \mathrm{~mL})$ induced with IPTG. Four Phlprol variants out of over 200 screened were selected for sequencing after showing two-fold higher activity with Leu-Pro at $30^{\circ} \mathrm{C}$ and somewhat reduced activity at $100^{\circ} \mathrm{C}$ as compared to wild type. The increased activity at the lower temperature of $30^{\circ} \mathrm{C}$ and variation at the higher temperature of $100^{\circ} \mathrm{C}$ is indicative of a mutation in a thermophilic protein, which can compromise activity or stability at higher temperatures but could create more flexibility and increased catalysis at the lower temperatures.

3.3. Sequencing of Ph1prol Mutants. Prior to sequencing, the four Phlprol mutants were numbered $(10,19,35$, and 72 ) based solely on the order in which they had been isolated.

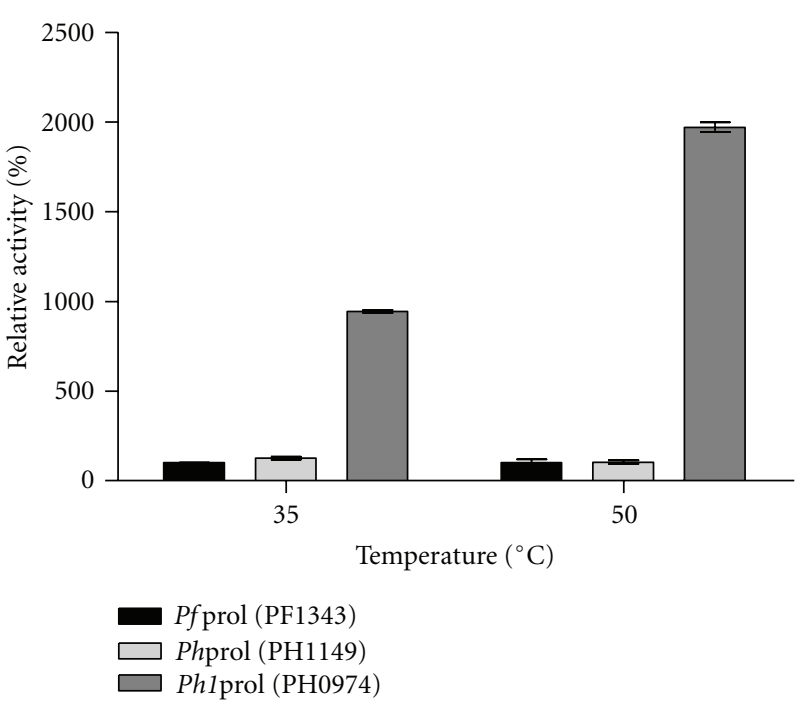

FIgURE 1: Relative activity with WT-Pfprol and P. horikoshii prolidases with OP nerve agent DFP. All prolidase assays contained $50 \mathrm{mM}$ MOPS, $200 \mathrm{mM} \mathrm{NaCl}, \mathrm{pH} 7.0,0.2 \mathrm{mM} \mathrm{CoCl}_{2}$, and $3 \mathrm{mM}$ DFP. $100 \%$ relative activity corresponds to WT-Pfprol specific activity for DFP of $0.42 \mu$ moles product formed $/ \mathrm{min} / \mathrm{mg}$ at $35^{\circ} \mathrm{C}$ and $0.73 \mu$ moles product formed $/ \mathrm{min} / \mathrm{mg}$ at $50^{\circ} \mathrm{C}$.

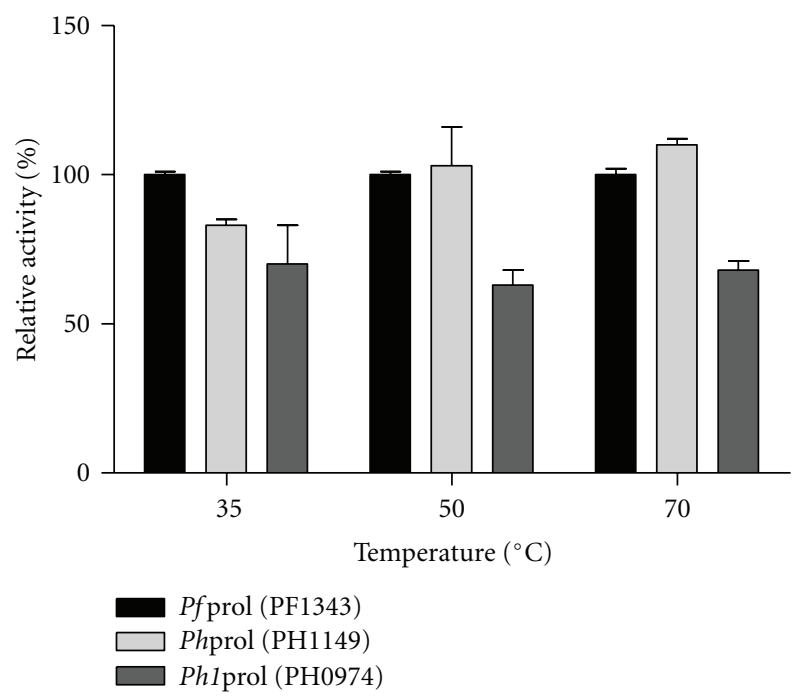

FIgure 2: Relative activity with WT-Pfprol and P. horikoshii prolidase with OP nerve agent analog, $p$-nitrophenyl soman. All prolidase assays contained $50 \mathrm{mM}$ MOPS $200 \mathrm{mM} \mathrm{NaCl} \mathrm{pH} 7.0$, $0.2 \mathrm{mM} \mathrm{CoCl}_{2}$, and $3 \mathrm{mM}$-nitrophenyl soman. One hundred percent relative activity corresponds to WT- $P f$ prol-specific activity for $p$-nitrophenyl soman of $0.26 \mu \mathrm{mol}$ product formed $/ \mathrm{min} / \mathrm{mg}$ at $35^{\circ} \mathrm{C}, 0.33 \mu \mathrm{mol}$ product formed $/ \mathrm{min} / \mathrm{mg}$ at $50^{\circ} \mathrm{C}$, and $0.56 \mu \mathrm{mol}$ product formed $/ \mathrm{min} / \mathrm{mg}$ at $70^{\circ} \mathrm{C}$.

Sequencing of the variants revealed the locations of the amino acid substitutions for each mutant (Figure 3). Mutant no.10 has two mutations: one at position 195 in which there is a change from alanine to threonine (A195T) and the second at amino acid residue 306 in which glycine is changed to serine (G306S). Both of these mutations reside 
in the C-terminal region of Phlprol. Mutant no.19 has two mutations: one at position 301 in which there is a change from tyrosine to cysteine (Y301C) and the second at amino acid residue 342 which has a substitution of lysine with an asparagine $(\mathrm{K} 342 \mathrm{~N})$. Both of these mutations are in the C-terminal region of the enzyme. Mutant no.35 contains two mutations: one at position 127 in the $\alpha$-helical linker region in which there is a change from glutamate to glycine $(\mathrm{E} 127 \mathrm{G})$ and the second in the C-terminal region at position 252 with a substitution of glutamate for aspartate (E252D). Mutant no.72 is the only mutation in the Nterminal region at position 36 with a change from glutamate to valine (E36V) in Phlprol. The mutations are remote from the active site pocket, which is shown in Figure 3 as being located between two $3_{10}$ helixes (red helices, residues 191-195, and 281-284). Therefore, the mutations are not likely directly changing the active site chemistry. Rather the mutations such as E36V, E127G, and Y301C may be affecting prolidase dimerization as those residues are located along the dimerization interface. Furthermore, the mutations may be affecting the conformational dynamics of the enzymes since some of the mutations are located in the loop and linker regions. The change in conformation dynamics is giving the variants better activity over a broader range of temperatures as indicated in Section 3.4.

3.4. Effects of Mutagenesis on the Temperature Profile of $P$. horikoshii Prolidase Variants. Both the wild type Phlprol and the four variants were most active at $100^{\circ} \mathrm{C}$ (Figure 4). WTPhlprol and E36V-Phlprol had very high specific activities $(3,955 \mathrm{U} / \mathrm{mg}$ and $4094 \mathrm{U} / \mathrm{mg}$, resp.) with $4 \mathrm{mM}$ Met-Pro, both of which are twice as high as that of $P f$ prol at $100^{\circ} \mathrm{C}$ $(2,154 \mathrm{U} / \mathrm{mg})$ [21]. A195T/G306S- and E127G/E252DPhlprol were slightly less active $(2,307 \mathrm{U} / \mathrm{mg}$ and 2,831 U/mg, resp.) than WT Phlprol, and Y301C/K342NPhlprol showed the lowest level of activity in comparison to the other mutants at $1,842 \mathrm{U} / \mathrm{mg}$. Activity was reduced by more than half at $70^{\circ} \mathrm{C}$ for all of the variants; however, WTPhlprol, A195T/G306S-, and E36V-Phlprol all had specific activities close to $1,000 \mathrm{U} / \mathrm{mg}$ ( $973 \mathrm{U} / \mathrm{mg}, 1000 \mathrm{U} / \mathrm{mg}$, and $913 \mathrm{U} / \mathrm{mg}$, resp.), whereas the specific activity of $P f$ prol at $70^{\circ} \mathrm{C}$ was $806 \mathrm{U} / \mathrm{mg}[21]$. At $50^{\circ} \mathrm{C}, \mathrm{Y} 301 \mathrm{C} / \mathrm{K} 342 \mathrm{~N}-\mathrm{Ph} 1$ prol had a higher specific activity than any of the other variants and the wild type $(450 \mathrm{U} / \mathrm{mg})$ and was roughly three times more active than $P f$ prol at $50^{\circ} \mathrm{C}$ [21].

At the lower temperatures, $35^{\circ} \mathrm{C}, 20^{\circ} \mathrm{C}$ and $10^{\circ} \mathrm{C}$, Y301C/K342N-Phlprol out-performs the other Phlprol variants, the WT-Phlprol, the WT-Pfprol and R19G/G39E/ K71E/S229T- $P f$ prol (the highest performing $P f$ prol mutant at lower temperatures) [21]. At $35^{\circ} \mathrm{C}, \mathrm{Y} 301 \mathrm{C} / \mathrm{K} 342 \mathrm{~N}$ Phlprol $(298 \mathrm{U} / \mathrm{mg}$ ) has relative activity that is $121 \%$ that of WT-Phlprol, $489 \%$ that of WT-Pf prol, and $244 \%$ that of R19G/G39E/K71E/S229T-Pf prol (246 U/mg, $61 \mathrm{U} / \mathrm{mg}$, and $122 \mathrm{U} / \mathrm{mg}$, resp.). At $20^{\circ} \mathrm{C}, \mathrm{Y} 301 \mathrm{C} / \mathrm{K} 342 \mathrm{~N}-\mathrm{Ph} 1$ prol $(241 \mathrm{U} / \mathrm{mg})$ has a relative activity $184 \%$ that of WTPh1prol, 964\% higher than WT-Pf prol, and $482 \%$ higher than R19G/G39E/K71E/S229T-Pf prol (specific activities of $131 \mathrm{U} / \mathrm{mg}$ for WT-Ph1prol, $25 \mathrm{U} / \mathrm{mg}$ for WT-Pfprol and

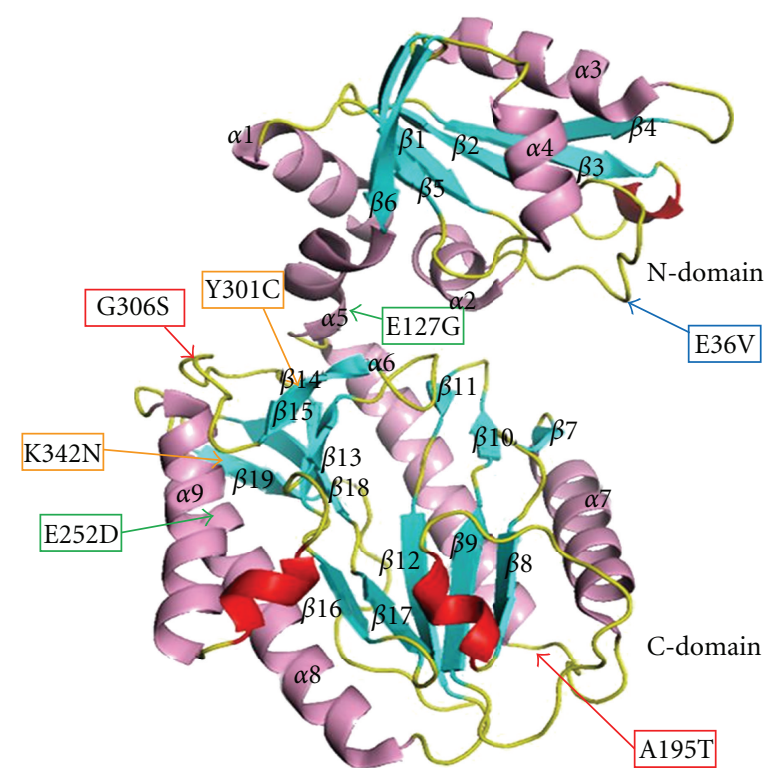

FIgURE 3: Mapping of the mutations in the monomeric structure of P. horikoshii prolidase (Phlprol or PH0974). Mutations made in the Phlprol are indicated by colored arrows where red indicates mutations present in Mutant no.10 (A195T/G306S-Ph1prol), orange indicates mutations in Mutant no.19 (Y301C/K342N), green indicates mutations in Mutant no.35 (E127G/E252D), and blue indicates mutations in Mutant no.72 (E36V). The domain structure of $\mathrm{Ph} 1 \mathrm{prol}$ is presented as a ribbon drawing where the N-terminal (residues 1-120) and C-terminal (131-356) domains are labeled and are connected by a $\alpha$-helical linker at residues $121-130$. The putative active site pocket is located between two $3_{10}$ helixes (two red helices, residues 191-195 and 281-284) (modified from [18]).

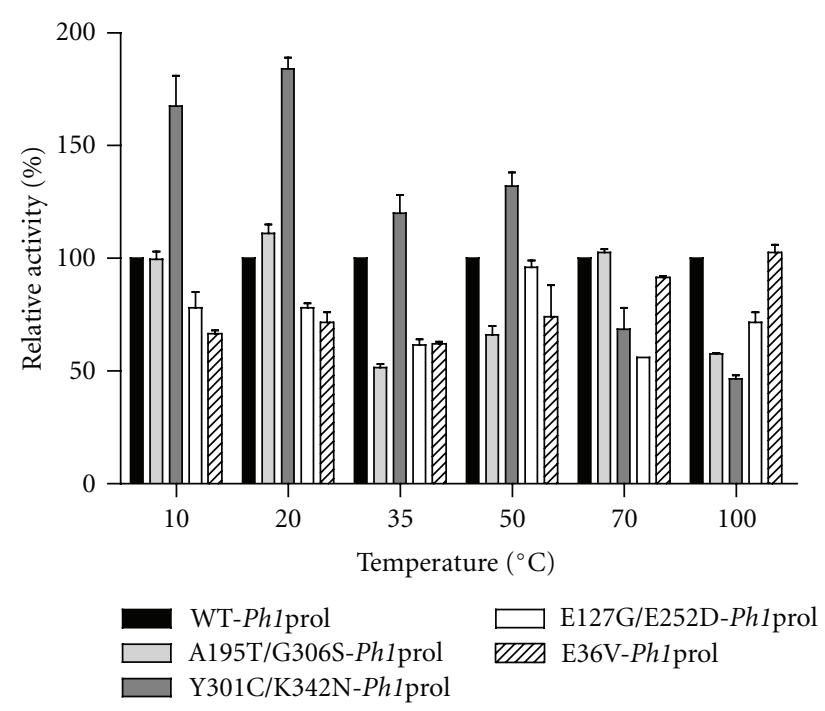

FIGURE 4: Temperature profile of WT-Phlprol and the four variants. Relative activities are shown as a percentage of the WT-Phlprol. Prolidase assays were performed in triplicate at $10^{\circ} \mathrm{C}, 20^{\circ} \mathrm{C}$, $35^{\circ} \mathrm{C}, 50^{\circ} \mathrm{C}, 70^{\circ} \mathrm{C}$, and $100^{\circ} \mathrm{C}$ and contained $0.2 \mathrm{mM} \mathrm{CoCl}_{2}$ and $4 \mathrm{mM}$ Met-Pro. WT-Phlprol-specific activity was $66 \mathrm{U} / \mathrm{mg}$ at $10^{\circ} \mathrm{C}$, $131 \mathrm{U} / \mathrm{mg}$ at $20^{\circ} \mathrm{C}, 246 \mathrm{U} / \mathrm{mg}$ at $35^{\circ} \mathrm{C}, 340 \mathrm{U} / \mathrm{mg}$ at $50^{\circ} \mathrm{C}, 973 \mathrm{U} / \mathrm{mg}$ at $70^{\circ} \mathrm{C}$, and $3,955 \mathrm{U} / \mathrm{mg}$ at $100^{\circ} \mathrm{C}$. 
$50 \mathrm{U} / \mathrm{mg}$ for R19G/G39E/K71E/S229T-Pf prol) [21]. The greatest improvement in performance for the $P h 1$ prol mutants is seen when assayed at $10^{\circ} \mathrm{C}$. $\mathrm{Y} 301 \mathrm{C} / \mathrm{K} 342 \mathrm{~N}-\mathrm{Ph} 1 \mathrm{prol}$ $(109 \mathrm{U} / \mathrm{mg}$ ) has a relative activity that is $166 \%$ higher than that of WT-Ph1prol, 1,982\% higher than that of WT-Pf prol, and 396\% higher than R19G/G39E/K71E/S229T-Pf prol (specific activities of $66 \mathrm{U} / \mathrm{mg}$ for WT-Ph1prol, $5.5 \mathrm{U} / \mathrm{mg}$ for WT-Pf prol, and $27.5 \mathrm{U} / \mathrm{mg}$ for R19G/G39E/K71E/S229TPf prol) [21].

3.5. Effects of Mutagenesis on Substrate Specificity and Kinetics of P. horikoshii Prolidase Variants. Substrate specificity of WT-Ph1prol is shown in Table 1 along with the specific activities of A195T/G306S-, Y301C/K342N-, E127G/E252D-, and E36V-Ph1prol, which are reported as a percentage relative to the activity of the wild type. WT-Phlprol was most active with the dipeptide Val-Pro $(4,602 \mathrm{U} / \mathrm{mg})$, while mutants A195T/G306S-, Y301C/K342N-, E127G/E252D-, and E36VPhlprol had much lower activity at 33\%, 36\%, 46\%, and 56\% of the WT Phlprol, respectively. A195T/G306SPhlprol showed the highest activity with Met-Pro at $143 \%$ that of the wild type $(2,809 \mathrm{U} / \mathrm{mg})$, while $\mathrm{Y} 301 \mathrm{C} / \mathrm{K} 342 \mathrm{~N}-$, E127G/E252D-, and E36V-Ph1prol preferred Ala-Pro with specific activities of $183 \%, 324 \%$, and $556 \%$ that of WTPhlprol (1,452 U/mg). WT-Ph1prol seems to prefer the most hydrophobic amino acids, while the four variants have the highest activity with a less hydrophobic amino acid in the Nterminal position of the dipeptide substrate. While alanine is considered to be a hydrophobic amino acid, it is less hydrophobic than valine, methionine, phenylalanine, and leucine and is most similar in structure to glycine. WTPhlprol has much lower activity with Gly-Pro than with Ala-Pro (369 compared to 1,452 U/mg). A195T/G306S-, Y301C/K342N-, and E127G/E252D-Ph1prol have less or similar activity with Gly-Pro as compared to WT-Phlprol (369 U/mg) while E36V-Ph1prol has 444\% higher activity.

Specific activities were consistently low with both ProAla and Val-Leu-Pro (2U/mg, WT-Phlprol) for the wild type $P h 1$ prol and the four mutants. Due to the nature of the prolidase enzyme and its unique ability to cleave the bond between Xaa-Pro dipeptides, it was expected that the enzyme would not show any notable activity with a ProXaa dipeptide or a tripeptide. While two of the four variants (mutants A195T/G306S- and E36V-Ph1prol) show increased activity with Pro-Ala when compared to wild type, it must be noted that specific activity with Pro-Ala for WT-Phlprol was extremely low, at only $14 \mathrm{U} / \mathrm{mg}$. Y301C/K342N-Phlprol had $88 \%$ WT activity with Val-Leu-Pro; however, WT-Phlprolspecific activity was only $2 \mathrm{U} / \mathrm{mg}$.

The catalytic activities of WT-Phlprol and its mutants were tested at $70^{\circ} \mathrm{C}$ with Leu-Pro (Table 2). All Phlprol mutants had higher $k_{\text {cat }}$ values than the WT-Phlprol suggesting that the amino acid changes in the mutant enzymes did have an effect on structure and ultimately the catalytic activity of the prolidase with the substrate Leu-Pro. Although the $k_{\text {cat }}$ values were higher, the overall enzyme turnover rates were not for some of the mutants compared to WT-Phlprol.
TABLE 1: Substrate specificity of recombinant wild type and variant $P$. horikoshii prolidases with different proline dipeptides and a single-proline tripeptide.

\begin{tabular}{|c|c|c|c|c|c|}
\hline \multirow[t]{2}{*}{ Substrate } & \multicolumn{5}{|c|}{ Relative Activity (\%) of WT-Phlprol-specific activity } \\
\hline & $\begin{array}{c}\text { WT- } \\
\text { Ph1prol }\end{array}$ & $\begin{array}{l}\text { A195T/ } \\
\text { G306S- } \\
\text { Ph1prol }\end{array}$ & $\begin{array}{l}\text { Y301C/ } \\
\text { K342N- } \\
\text { Ph1prol }\end{array}$ & $\begin{array}{l}\text { E127G/ } \\
\text { E252D- } \\
\text { Ph1prol }\end{array}$ & $\begin{array}{l}\text { E36V- } \\
\text { Ph1prol }\end{array}$ \\
\hline Val-Pro & $\begin{array}{c}100 \\
(4,602)\end{array}$ & 33 & 36 & 46 & 56 \\
\hline Met-Pro & $\begin{array}{c}100 \\
(2,809)\end{array}$ & 143 & 33 & 117 & 77 \\
\hline Phe-Pro & $\begin{array}{c}100 \\
(2,199)\end{array}$ & 116 & 53 & 53 & 68 \\
\hline Leu-Pro & $\begin{array}{c}100 \\
(2,132)\end{array}$ & 116 & 36 & 90 & 65 \\
\hline Ala-Pro & $\begin{array}{c}100 \\
(1,452)\end{array}$ & 219 & 183 & 324 & 556 \\
\hline Gly-Pro & $\begin{array}{c}100 \\
(369)\end{array}$ & 94 & 52 & 107 & 444 \\
\hline Pro-Ala & $\begin{array}{l}100 \\
(14)\end{array}$ & 137 & 33 & 75 & 332 \\
\hline Val-Leu-Pro & $\begin{array}{l}100 \\
(2)\end{array}$ & 0 & 88 & 0 & 0 \\
\hline
\end{tabular}

Prolidase assays were performed at $100^{\circ} \mathrm{C}$ and contained $0.2 \mathrm{mM} \mathrm{CoCl}_{2}$ and $4 \mathrm{mM}$ of each substrate. One hundred percent specific activity is reported for WT-Phlprol and correlates to U/mg in parentheses below the $100 \%$ relative activity.

Table 2: Kinetic parameters of wild type Pyrococcus horikoshii prolidase, $P h 1$ prol, and prolidase variants with Leu-Pro at $70^{\circ} \mathrm{C}$.

\begin{tabular}{lcccc}
\hline Prolidase & $\begin{array}{c}K_{m} \\
(\mathrm{mM})\end{array}$ & $\begin{array}{c}V_{\max } \\
(\mu \mathrm{mol} / \mathrm{min} / \mathrm{mg})\end{array}$ & $\begin{array}{c}k_{\mathrm{cat}} \\
\left(\mathrm{s}^{-1}\right)\end{array}$ & $\begin{array}{c}k_{\mathrm{cat}} / K_{m} \\
\left(\mathrm{mM}^{-1} \mathrm{~s}^{-1}\right)\end{array}$ \\
\hline WT-Ph1prol & $0.92 \pm 0.16$ & $809 \pm 55$ & 1079 & 1172 \\
A195T/G306S & $0.81 \pm 0.26$ & $1245 \pm 149$ & 1660 & 2049 \\
Y301C/K342N & $2.92 \pm 0.40$ & $2146 \pm 177$ & 2861 & 980 \\
E127G/E252D & $0.98 \pm 0.24$ & $1119 \pm 101$ & 1492 & 1522 \\
E36V & $1.6 \pm 0.37$ & $1597 \pm 174$ & 2129 & 1331 \\
\hline
\end{tabular}

Enzyme assays were done using a range of Leu-Pro concentrations (0.25$12 \mathrm{mM}$ ). Enzyme kinetics were calculated using nonlinear regression (curve fit) and analyzed using the Michaelis-Menten equation utilizing software from Prism 5 (GraphPad La Jolla, CA). All Ph1prol assays contained $0.2 \mathrm{mM}$ $\mathrm{CoCl}_{2}$.

All the $P h 1$ prol mutants showed an increased turnover rate, $k_{\text {cat }} / K_{m}$, with Leu-Pro except for Y301C/K342N-Ph1prol. This could be due to the increase in the $K_{m}$ of this mutant, which is almost three times higher than WT-Phlprol.

3.6. Effects of Amino Acid Substitutions on the Thermostability and Pot-Life Activity of P. horikoshii Prolidase Mutants. To determine whether the amino acid substitutions in the four Phlprol variants had any effect on thermostability, the mutants were incubated in sealed vials at $90^{\circ} \mathrm{C}$, anaerobically, for $72 \mathrm{~h}$. Samples were taken every $24 \mathrm{~h}$ to measure 
catalytic activity with Met-Pro $(4 \mathrm{mM})$ as the substrate. In Theriot et al. 2010, it was shown that WT-Pf prol was more thermostable than its mutants and had lost $50 \%$ activity with Met-Pro by 21 hours at $90^{\circ} \mathrm{C}[20]$. After $40 \mathrm{~h}$ at $90^{\circ} \mathrm{C}$, WT-Phlprol had lost 50\% activity. Mutants Y301C/K342NPhlprol and E127G/E252D-Phlprol both demonstrated increased thermostability at $90^{\circ} \mathrm{C}$ compared to wild type and had lost $50 \%$ activity after 58 hours of incubation. Mutants A195T/G306S-Phlprol and E36V-Phlprol displayed a 50\% loss of activity after 32 and 35 hours at $90^{\circ} \mathrm{C}$, respectively. Both WT-Phlprol and the four Phlprol mutants were stable at $90^{\circ} \mathrm{C}$ for a significantly longer time period than $P f$ prol and its mutants [20].

Pot-life activity was monitored over the course of 21 days with samples taken every seven days until day 14 and then again on days 16 and 21 while the samples were incubated anaerobically at $70^{\circ} \mathrm{C}$ (Figure 5). Pot-life experiments with WT-Pf prol and its mutants as reported in Theriot et al., 2010 were conducted over a $48 \mathrm{~h}$ period at $70^{\circ} \mathrm{C}[20]$. In preliminary pot-life experiments with WT-Phlprol and its mutants, the specific activities with Met-Pro were still remarkably high after $48 \mathrm{~h}$ (no obvious decrease in specific activity was detected; data not shown), so the experiments were continued until the enzymes were considered to be no longer active (21 days). Initial specific activities for WT-Phlprol, A195T/G306S-, Y301C/K342N-, E127 G/E252 D-, and E36V-Phlprol were $3,150 \mathrm{U} / \mathrm{mg}, \quad 3,400 \mathrm{U} / \mathrm{mg}, \quad 1,250 \mathrm{U} / \mathrm{mg}, \quad 2,200 \mathrm{U} / \mathrm{mg}$, and $3,600 \mathrm{U} / \mathrm{mg}$, respectively, with $4 \mathrm{mM}$ Met-Pro as the substrate. WT-Phlprol had lost $50 \%$ activity by day 12 of incubation at $70^{\circ} \mathrm{C}$. Mutants $\mathrm{Y} 301 \mathrm{C} / \mathrm{K} 342 \mathrm{~N}-$, E127G/E252D-, and $\mathrm{E} 36 \mathrm{~V}-\mathrm{Ph} 1$ prol had $50 \%$ activity remaining by days 12 , 13 , and 14, respectively. A195T/G306S-Ph1prol was at 50\% activity after 10 days at $70^{\circ} \mathrm{C}$. By 21 days at $70^{\circ} \mathrm{C}$, all five prolidases were at or below $25 \%$ of the initial activity.

As reported in Theriot et al., 2010, the specific activities of WT-Pfprol and its three mutants (G39E-, R19G/K71E/S229T-, and R19G/G39E/K71E/S229T-Pf prol) were $1,083 \mathrm{U} / \mathrm{mg}, 599 \mathrm{U} / \mathrm{mg}, 722 \mathrm{U} / \mathrm{mg}$, and $4,496 \mathrm{U} / \mathrm{mg}$, respectively, with $4 \mathrm{mM}$ Met-Pro after $48 \mathrm{~h}$ of incubation at $70^{\circ} \mathrm{C}[20]$. In contrast, after 7 days $\left(\right.$ or $168 \mathrm{~h}$ ) at $70^{\circ} \mathrm{C}$, WTPh1prol, A195T/G306S-, Y301C/K342N-, E127G/E252D-, and E36V-Phlprol had specific activities of $2,950 \mathrm{U} / \mathrm{mg}$, $3,050 \mathrm{U} / \mathrm{mg}, \quad 1,230 \mathrm{U} / \mathrm{mg}, 2,650 \mathrm{U} / \mathrm{mg}$, and $2,400 \mathrm{U} / \mathrm{mg}$, respectively, with $4 \mathrm{mM}$ Met-Pro. After $48 \mathrm{~h}$ at $70^{\circ} \mathrm{C}$, WTPf prol had a higher specific activity than any of its mutants $(1,083 \mathrm{U} / \mathrm{mg})$. After 7 days at $70^{\circ} \mathrm{C}, \mathrm{Y} 301 \mathrm{C} / \mathrm{K} 342 \mathrm{~N}-\mathrm{Ph} 1 \mathrm{prol}$ showed the lowest specific activity of the $P h 1$ prolidases; however, it still had activity $114 \%$ that of WT-Pf prol at $48 \mathrm{~h}$ [20].

3.7. DSC Results. The thermal stability of wild type Phlprol and variants was determined by differential scanning calorimetry (DSC) experiments. Table 3 shows the denaturation temperature of the wild type and variant enzymes. The mutations that improved catalytic activity of the Phlprol at lower temperatures did not adversely affect the temperature stability of the enzymes.
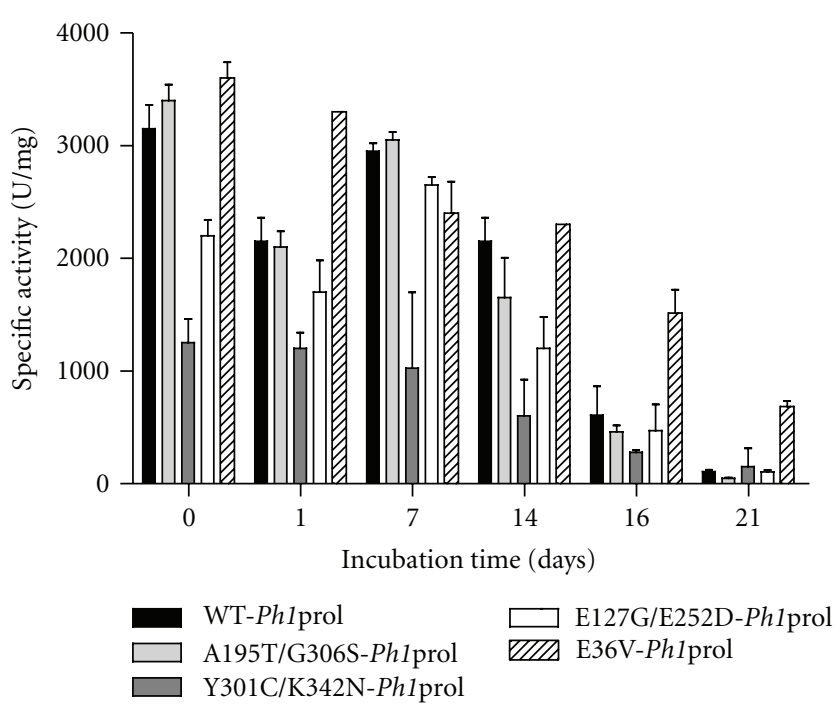

Figure 5: Pot-life activity of WT-Phlprol and prolidase mutants incubated anaerobically at $70^{\circ} \mathrm{C}$. Pot-life experiments were performed in duplicate and samples were taken at $0,1,7,14,16$, and 21 days to assess reactivity. Prolidase assays were performed in triplicate at $100^{\circ} \mathrm{C}$ and contained $0.2 \mathrm{mM} \mathrm{CoCl}_{2}$ and $4 \mathrm{mM}$ MetPro. Error bars in Figure 5 represent standard deviation of specific activity across duplicate runs.

TABle 3: Transition temperature of wild type Pyrococcus horikoshii prolidase, $\mathrm{Ph} 1 \mathrm{prol}$, and prolidase variants at $\mathrm{pH}$ 7.0.

\begin{tabular}{lc}
\hline Prolidase & $T_{m}\left({ }^{\circ} \mathrm{C}\right)$ \\
\hline WT-Ph1prol & $114.3 \pm 1.1$ \\
A195T/G306S ${ }^{1}$ & $114.4 \pm 0.1$ \\
Y301C/K342N & $113.8 \pm 0.6$ \\
E127G/E252D & $112.2 \pm 0.5$ \\
E36V & $114.9 \pm 1.3$ \\
\hline
\end{tabular}

$T_{m}$ is the transition temperatures obtained from the analysis of DSC by using the two-state model. The $T_{m}$ values are the mean of three independent measurements. ${ }^{1}$ The $T_{m}$ value is from two independent measurements.

3.8. Effects of Amino Acid Substitutions on Substrate Specificity with OP Nerve Agents DFP and Soman Analog, p-Nitrophenyl Soman. Substrate specificity of WT-Phlprol with DFP is shown in Figure 6 along with the specific activities of A195T/G306S-, Y301C/K342N-, E127G/E252D-, and E36VPhlprol, which are reported as a percentage relative to the activity of the wild type. WT-Phlprol was most active with DFP at $35^{\circ} \mathrm{C}$ and $50^{\circ} \mathrm{C}$ with a specific activity of $4 \mathrm{U} / \mathrm{mg}$ and $10 \mathrm{U} / \mathrm{mg}$, respectively. The mutants A195T/G306S, Y301C/K342N-, E127G/E252D-, and E36V-Phlprol had significantly lower activity with DFP; even at $50^{\circ} \mathrm{C}$ the activity was only $59 \%, 25 \%$, and $55 \%$ of WT-Phlprol activity. However, it should be noted that the Phlprol mutants have 808\%, 183\%, and 402\% (A195T/G306S, Y301C/K342N-, E127G/E252D-, and E36V-Ph1prol, resp.) of the DFP activity compared to WT P. furiosus prolidase and also compared favorably to the highest DFP activity reported 


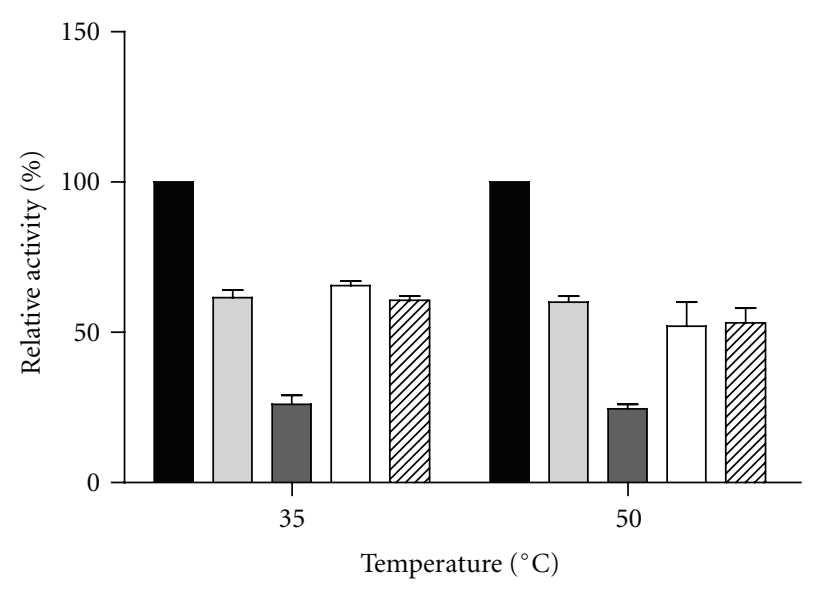

WT-Phlprol
$\square$ A195T/G306S-Ph1prol
$\square$ Y301C/K342N-Ph1prol

FIGURE 6: Relative activity with WT-Phlprol and prolidase mutants with OP nerve agent DFP. All prolidase assays contained $50 \mathrm{mM}$ MOPS $200 \mathrm{mM} \mathrm{NaCl} \mathrm{pH} \mathrm{7.0,} 0.2 \mathrm{mM} \mathrm{CoCl}_{2}$, and $3 \mathrm{mM} \mathrm{DFP.}$ One hundred percent relative activity corresponds to WT-Ph1prol specific activity for DFP of $4 \mu \mathrm{mol}$ product formed per minute per milligram at $35^{\circ} \mathrm{C}$ and $10 \mu \mathrm{mol}$ of product formed per minute per milligram at $50^{\circ} \mathrm{C}$.

for the R19/G39E/K71E/S229T Pf prol mutant, which was shown to have $398 \%$ higher activity than WT Pfprol [21].

Figure 7 reveals a different trend, where the mutations in WT-Phlprol increased the specific activity with the soman analog, $p$-nitrophenyl soman. WT-Phlprol showed the highest activity with the soman analog at $70^{\circ} \mathrm{C}$, with a specific activity of $0.56 \mathrm{U} / \mathrm{mg}$. The mutant A195T/G306SPhlprol had a similar specific activity to WT-Phlprol when incubated at $35^{\circ} \mathrm{C}, 50^{\circ} \mathrm{C}$, and $70^{\circ} \mathrm{C}$. Mutants $\mathrm{Y} 301 \mathrm{C} / \mathrm{K} 342 \mathrm{~N}$-, E127G/E252D-, and E36V-Ph1prol showed increased activity with the soman analog over WT-Phlprol at each assay temperature. The most significant specific activities with the soman analog were seen with $\mathrm{Y} 301 \mathrm{C} / \mathrm{K} 342 \mathrm{~N}$-, E127G/E252D-, and E36V-Phlprol at $70^{\circ} \mathrm{C}$, which correlated to $125 \%, 186 \%$, and $157 \%$ increase over WTPhlprol. Furthermore, the activities for the Phlprol mutants against $p$-nitrophenyl soman $(0.7,1.0$, and $0.9 \mathrm{U} / \mathrm{mg}$ for Y301C/K342N-, E127G/E252D-, and E36V-Ph1prol, resp.) compare favorably to the improved soman analog activities reported for the P. furiosus prolidase mutants $(0.86$, 1.02 , and $1.7 \mathrm{U} / \mathrm{mgfor}$ G39E-, R19G/K71E/S229T-, and R19G/G39E/K71E/S229T-Pf prol, resp.) [20]. When looking at the substrate specificity of the WT-Phlprol and variants with proline dipeptides, it was noticed that there was a shift in preference from more hydrophobic to less hydrophobic amino acids among the mutants. This is also seen with the OP nerve agents, where there is a shift in substrate specificity from DFP to the soman analog. The WT-Phlprol prefers DFP as a substrate over the soman analog, while the Phlprol variants show decreased activity with DFP and increased activity with the soman analog.
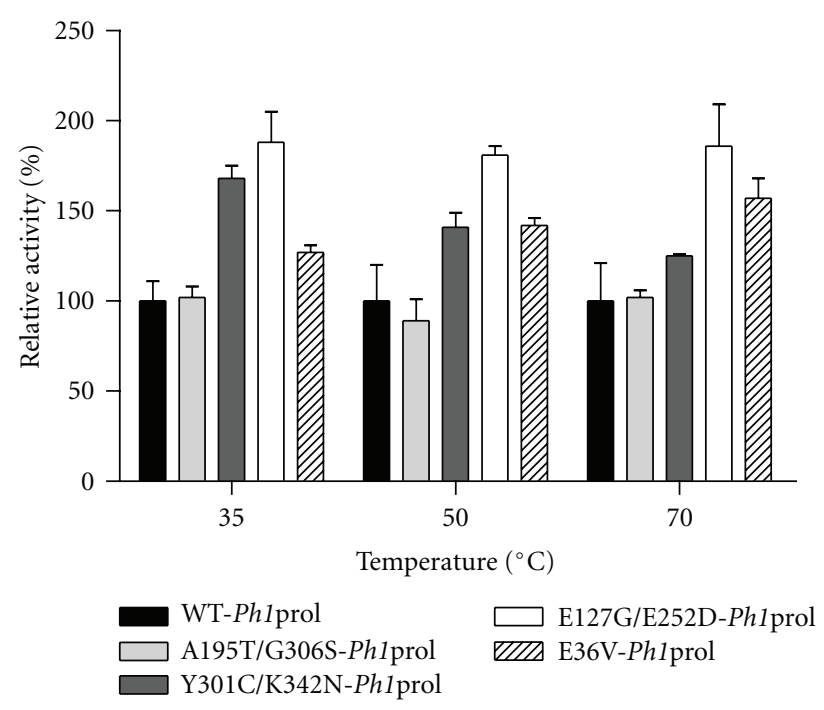

FIGURE 7: Relative activity with WT-Phlprol and prolidase mutants with OP nerve agent analog, $p$-nitrophenyl soman. All prolidase assays contained $50 \mathrm{mM}$ MOPS $200 \mathrm{mM} \mathrm{NaCl} \mathrm{pH} \mathrm{7.0,} 0.2 \mathrm{mM}$ $\mathrm{CoCl}_{2}$, and $3 \mathrm{mM}$ p-nitrophenyl soman. One hundred percent relative activity corresponds to WT-Phlprol specific activity for p-nitrophenyl soman of $0.26 \mu \mathrm{mol}$ product formed per minute per milligram at $35^{\circ} \mathrm{C}, 0.33 \mu \mathrm{mol}$ product formed per minute per milligram at $50^{\circ} \mathrm{C}$, and $0.56 \mu \mathrm{mol}$ product formed per minute per milligram at $70^{\circ} \mathrm{C}$.

\section{Conclusion}

Current biodecontamination formulations for degradation of OP nerve agents that incorporate Alteromonas prolidases (OPAA) and PTE have limitations when used in the field [12]. Long-term stability of the enzyme is not attainable in a formulation mixture that includes other solvents and denaturing solutions, and the need to add excess metal to reach maximum activity poses further complications for an enzyme-based detoxification system. A highly active enzyme that is stable over the long term and requires very little metal addition would be best suited for this application. The wild type and mutant prolidases characterized from $P$. horikoshii show promising enzymatic properties that make them potential candidates for future optimization studies for OP nerve agent degradation. Compared to $P f$ prol, Phlprol and the four $P h 1$ prol mutants show higher activity, higher affinity for the substrate, and significantly lower metal requirement for catalysis. Two of the variants, Y301C/K342N- and E127G/E252D-Ph1prol are thermostable for nearly three times as long as Pfprol and double the time of Phlprol. A195T/G306S-Ph1prol has $808 \%$ of the DFP activity compared to wild type $P$. furiosus prolidase and is superior to any of the improved P. furiosus prolidase mutants [21]. Furthermore, Y301C/K342N-, E127G/E252D-, and E36VPhlprol all have improved activities against $p$-nitrophenyl soman relative to WT-Phlprol and also compare favorably to the best performing P. furiosus prolidase mutants [20]. The Phlprol variants have the potential to significantly improve upon current biodecontamination strategies. Their increased thermostability and pot life and activities against 
OP nerve agent analogs warrant further study into large-scale production and purification of these prolidases.

\section{Acknowledgments}

The authors would like to thank Dr. Sherry Tove for her helpful comments on the paper and to acknowledge Dr. Nathaniel Hentz and Jessica Weaver at the NCSU Biomanufacturing Training and Education Center (BTEC) for contributing their time and expertise for the purification and characterization of the prolidases. They would like to thank Dr. James Carney and Patricia Buckley for performing the DSC experiment. Support for this study was provided by the Army Research Office (Contract no. 44258LSSR).

\section{References}

[1] J. M. González, Y. Masuchi, F. T. Robb et al., "Pyrococcus horikoshii sp. nov., a hyperthermophilic archaeon isolated from a hydrothermal vent at the Okinawa Trough," Extremophiles, vol. 2, no. 2, pp. 123-130, 1998.

[2] G. Fiala and K. O. Stetter, "Pyrococcus furiosus sp. nov. represents a novel genus of marine heterotrophic archaebacteria growing optimally at $100 \circ \mathrm{C}$," Archives of Microbiology, vol. 145, no. 1, pp. 56-61, 1986.

[3] M. W. W. Adams, "Enzymes and proteins from organisms that grow near and above $100 \circ$ C," Annual Review of Microbiology, vol. 47, pp. 627-658, 1993.

[4] J. Synowiecki, B. Grzybowska, and A. Zdziebło, "Sources, properties and suitability of new thermostable enzymes in food processing," Critical Reviews in Food Science and Nutrition, vol. 46, no. 3, pp. 197-205, 2006.

[5] S. E. Blumer-Schuette, I. Kataeva, J. Westpheling, M. W. Adams, and R. M. Kelly, "Extremely thermophilic microorganisms for biomass conversion: status and prospects," Current Opinion in Biotechnology, vol. 19, no. 3, pp. 210-217, 2008.

[6] L. D. Unsworth, J. Van Der Oost, and S. Koutsopoulos, "Hyperthermophilic enzymes - stability, activity and implementation strategies for high temperature applications," The FEBS Journal, vol. 274, no. 16, pp. 4044-4056, 2007.

[7] K. Egorova and G. Antranikian, "Industrial relevance of thermophilic Archaea," Current Opinion in Microbiology, vol. 8, no. 6, pp. 649-655, 2005.

[8] C. M. Theriot, S. R. Tove, and A. M. Grunden, "Biotechnological applications of recombinant microbial prolidases," in Advances in Applied Microbiology, A. Laskin, G. Gadd, and S. Sariaslani, Eds., vol. 68, pp. 99-132, Academic Press, New York, NY, USA, 2009.

[9] W. T. Lowther and B. W. Matthews, "Metalloaminopeptidases: common functional themes in disparate structural surroundings," Chemical Reviews, vol. 102, no. 12, pp. 4581-4607, 2002.

[10] T. C. Cheng, J. J. DeFrank, and V. K. Rastogi, "Alteromonas prolidase for organophosphorus G-agent decontamination," Chemico-Biological Interactions, vol. 119-120, pp. 455-462, 1999.

[11] T. C. Cheng, V. K. Rastogi, J. J. Defrank, and G. P. Sawiris, "Gtype nerve agent decontamination by Alteromonas prolidase," Annals of the New York Academy of Sciences, vol. 864, pp. 253258, 1998.

[12] N. K. Vyas, A. Nickitenko, V. K. Rastogi, S. S. Shah, and F. A. Quiocho, "Structural insights into the dual activities of the nerve agent degrading organophosphate anhydrolase/prolidase," Biochemistry, vol. 49, no. 3, pp. 547-559, 2010.

[13] C. M. Theriot and A. M. Grunden, "Hydrolysis of organophosphorus compounds by microbial enzymes," Applied Microbiology and Biotechnology, vol. 89, pp. 35-43, 2011.

[14] T. C. Cheng and J. J. DeFrank, "Hydrolysis of organophosphorus compounds by bacterial prolidases," in Enzymes in Action Green Solutions for Chemical Problems, B. Zwanenburg, M. Mikolajczyk, and P. Kielbasinski, Eds., vol. 33, Kluwer Academic, Dodrecht, The Netherlands, 2000.

[15] Joint Science and Technology Office for Chemical and Biological Defense FY 10/11-new initiatives. Defense Threat Reduction Agency, pp. 1-53, 2008.

[16] C. M. Theriot, S. R. Tove, and A. M. Grunden, "Characterization of two proline dipeptidases (prolidases) from the hyperthermophilic archaeon Pyrococcus horikoshii," Applied Microbiology and Biotechnology, vol. 86, no. 1, pp. 177-188, 2010.

[17] M. Ghosh, A. M. Grunden, D. M. Dunn, R. Weiss, and M. W. W. Adams, "Characterization of native and recombinant forms of an unusual cobalt- dependent proline dipeptidase (prolidase) from the hyperthermophilic archaeon Pyrococcus furiosus," Journal of Bacteriology, vol. 180, no. 18, pp. 47814789, 1998.

[18] J. Jeyakanthan et al., "Crystal structural and functional analysis of the putative dipeptidase from Pyrococcus horikoshii OT3," Journal of Biophysics, vol. 2009, Article ID 434038, 2009.

[19] M. J. Maher, M. Ghosh, A. M. Grunden et al., "Structure of the Prolidase from Pyrococcus furiosus," Biochemistry, vol. 43, no. 10, pp. 2771-2783, 2004.

[20] C. M. Theriot, X. Du, S. R. Tove, and A. M. Grunden, "Improving the catalytic activity of hyperthermophilic Pyrococcus prolidases for detoxification of organophosphorus nerve agents over a broad range of temperatures," Applied Microbiology and Biotechnology, vol. 87, no. 5, pp. 1715-1726, 2010.

[21] F. W. Studier, "Protein production by auto-induction in high density shaking cultures," Protein Expression and Purification, vol. 41, no. 1, pp. 207-234, 2005.

[22] C. M. Hill, W. S. Li, T. C. Cheng, J. J. DeFrank, and F. M. Raushel, "Stereochemical specificity of organophosphorus acid anhydrolase toward p-nitrophenyl analogs of soman and sarin," Bioorganic Chemistry, vol. 29, no. 1, pp. 27-35, 2001. 

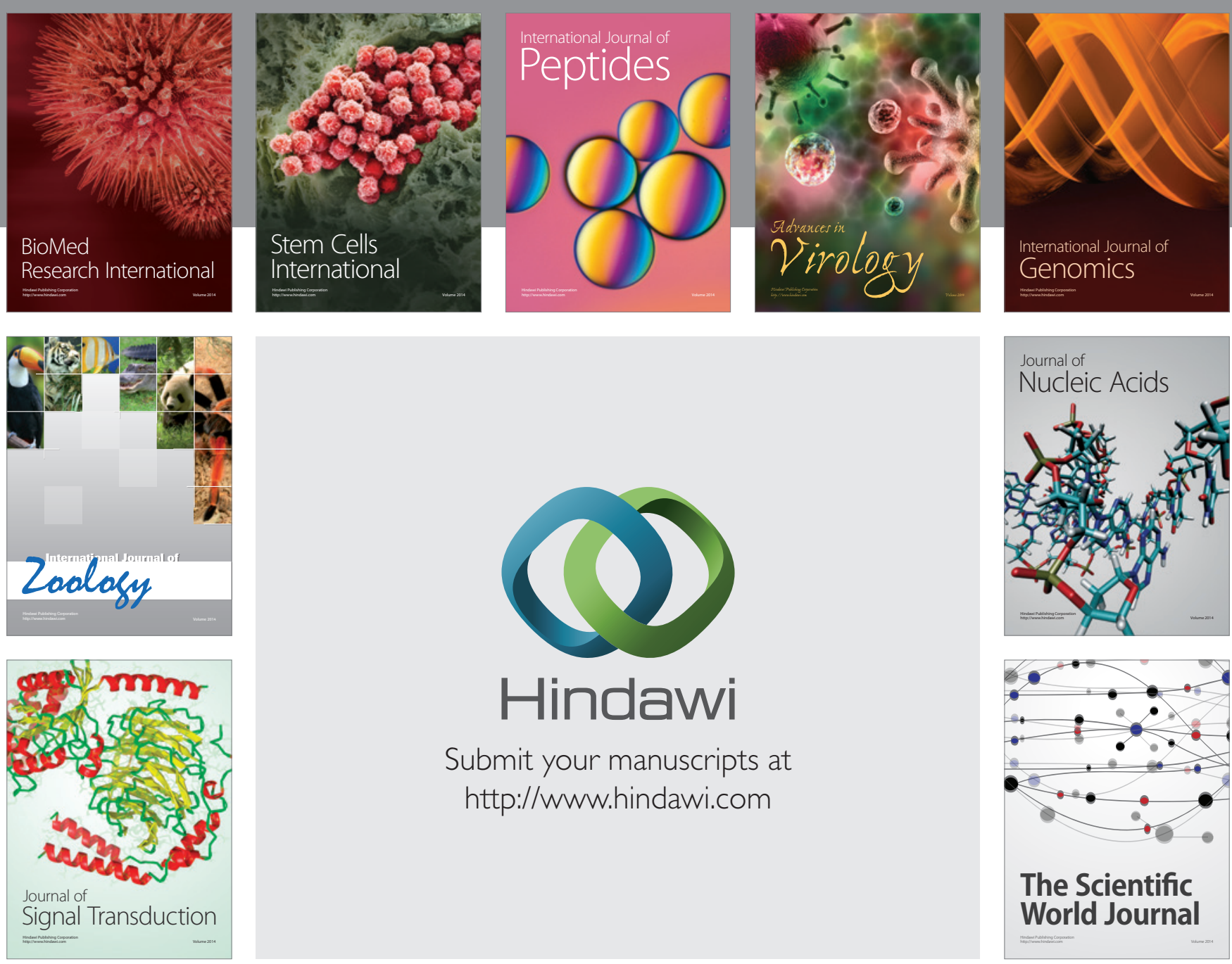

Submit your manuscripts at

http://www.hindawi.com
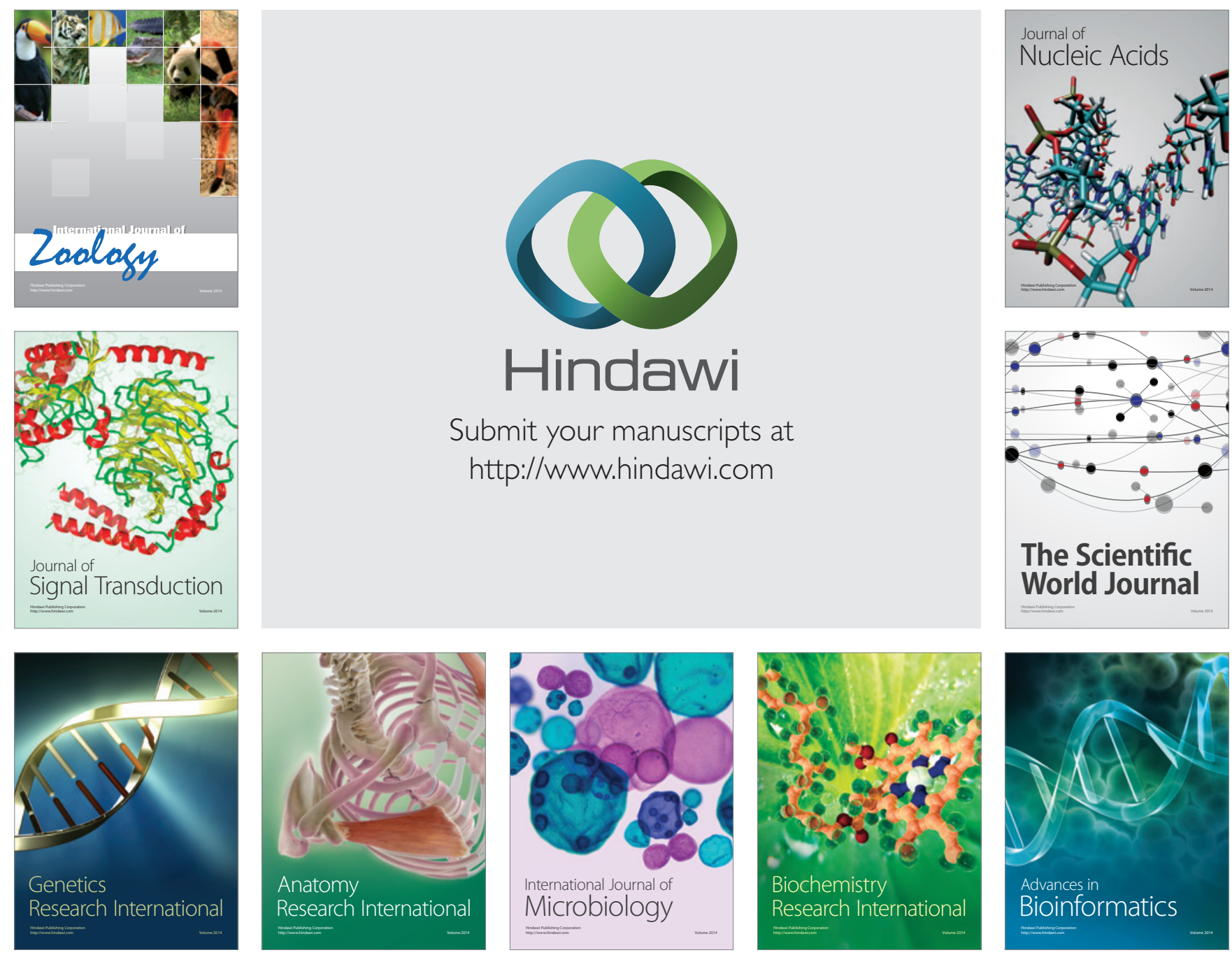

The Scientific World Journal
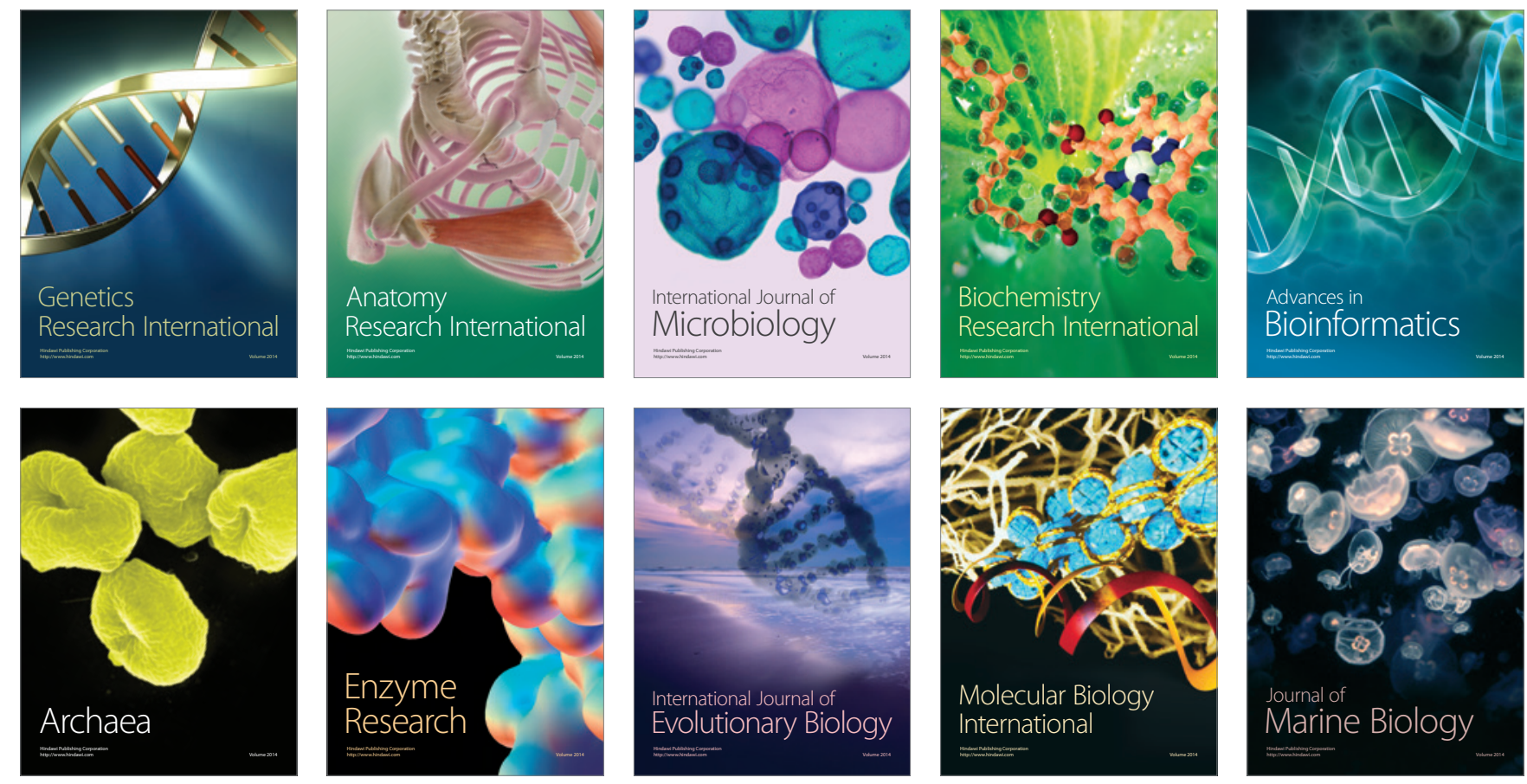